\title{
The Role of Essay Writing Course, Given along with Comprehension-based Instruction, on the Writing Skill Development of High School Students
}

\author{
Şule Yüksel Ertuğrul Seçer a * (D), Nadir Çeliköz b \\ a Air Academy, National Defense University, Yeșilyurt, İstanbul, 34149, Turkey \\ ${ }^{b}$ Educational Sciences, Ylldız Technical University, Davutpașa, İstanbul, 34220, Turkey
}

Received 22 July 2017 | Received in revised form 8 September 2017 | Accepted 11 September 2017

\begin{abstract}
This paper aims to analyze the effect of Essay Writing Course, given as specific writing skill instruction along with comprehension-based instruction, on the writing skill development of high school students. The paper is based on a quantitative study conducted in true experimental design. According to the Comprehension Hypothesis (Krashen, 1994, 2003), a comprehension-based instruction with an emphasis on reading and listening practice as receptive skills, will eventually lead to students' improvement in writing and speaking as productive skills, and to their overall language development. Besides, specific writing skill instruction and effective writing practices have a proven record of success in enhancing students' writing (Graham, 2018). Within the scope of this study, to determine if there is a meaningful difference in between the writing skill development of the students who take Essay Writing Course and of those who do not take any rhetorical course, apart from the comprehension-based instruction, the first and final writing exam scores and achievement levels of two groups of students are compared by a series of paired sample and independent t-tests, analyzed in SPSS and discussed in the scope of the study. It can be concluded from the results of the analysis that the experimental group, given the Essay Writing Course as writing skill instruction is significantly more successful than the control group, not given any writing skill instruction apart from comprehension oriented instruction. Within the analysis, done in the study, it can be also claimed that Essay Writing Course has a positive impact over the writing skill development of high school students.
\end{abstract}

(C) 2017 EJAL \& the Authors. Published by Eurasian Journal of Applied Linguistics (EJAL). This is an open-access article distributed under the terms and conditions of the Creative Commons Attribution license (CC BY-NC-ND) (http://creativecommons.org/licenses/by-nc-nd/4.0/).

Keywords: Writing skill; comprehension-based instruction; writing skill instruction

\section{Introduction}

Writing is critical to student success in education in all grades and levels. Generally, students' competence in writing skill aids their performance on achievement tests not only in writing, but also in other learning domains as well (Reeves, 2000; Graham \& Hebert, 2011). In addition, writing skill also serves as a key for employment and promotion in the workplace all over the world (Smart, 2008).

\footnotetext{
* Şule Yüksel Ertuğrul Seçer. Tel.: +0-533-668-9488 syertugrul@hho.edu.tr
} 
Furthermore, writing also serves many purposes in today's social life, even in the form of electronic personal communication such as text messages and emails for daily social interaction and self-expression. Together, these facts make writing have a central role in today's world of communication society. Despite its importance for the benefit of component writers in education, work and social life, writing still remains as a struggle for a large segment of the world's population, including the students, employees and professionals as well (Gökalp, 2001). Every year large numbers of adolescents fail to meet the requirements of the high school curriculum (Kamil, 2003; Snow \& Biancarosa, 2003). Even worse, many of the high school graduates unable to write at the basic levels required by universities or business owners (Alliance for Excellent Education, 2006). This intensifies the importance of writing skill improvement as an educational issue and loads the educators and instructors of writing with a huge work and responsibility to do their best to help improve learners' writing skills at high school level.

On the issue of language acquisition and skill development in second language, there can be said to be various viewpoints. Among all, a widely held view on second language acquisition is the comprehension-based hypothesis, according to which language learners acquire all kinds of language knowledge through direct and intensive exposure to comprehensible oral and written texts. The comprehensionbased approach, focusing on the acquisition of language knowledge through meaningfocused listening and reading comprehension activities, has initiated basically from the empirical research (Krashen, 1994, 2003). Gradman and Hanania (1991) study on the role of reading-based practice in second language acquisition, and conclude that reading outside the class is the major factor determining success in second language acquisition among a number of factors affecting second language development such as formal learning, intensive English activity, and communicative oral use. In parallel, extensive reading is claimed to have a crucial role in language acquisition and proficiency (Smith, 2003; Hitosugi \& Day, 2004). Furthermore, "reading recreationally" or "reading for fun" is reported to be positively correlated with reading competence (National Center for Education Statistics, 1997). Language acquirers also show dramatic gains from "free voluntary reading" and "pleasure reading" (Beglar, Hunt, \& Kite, 2011; Mason, 2006). Sustained silent reading (SSR) is also shown to be an effective technique of second language development as "reading aloud's natural partner" (Trelease, 2013). Moreover, some studies demonstrate that deliberate grammar instruction, and grammar correction have no lasting impact on language acquisition, but only influence conscious learning (Truscott, 2004, 2005). Bozorgian (2012) also contributes to the view that comprehension-based activities facilitate second language acquisition by indicating a high correlation between listening skill instruction and overall language proficiency.

In light of comprehension-based approach, receptive skills, listening and reading can be also claimed to have a positive effect over productive skills, writing and speaking. In comprehension-based approach, where learners concentrate on understanding, the development of listening comprehension ability precedes the 
development of speaking ability, and fluent reading of age and level appropriate texts facilitates the development of composition skills (Paribakht \& Wesche, 1993). In other words, receptive knowledge and development in receptive skills, which are listening and reading, will form the basis to produce utterances and result in development of productive skills, writing and speaking in the language In his study on the effect of listening skill instruction over the improvement of composition, Berninger (2000) points out a high correlation between the improvement of narrative and expository composition through listening instruction since the participants between 1st and 6th grades show a significant improvement in spelling through aural skill instruction. Moreover, Shanahan (2006) emphasizes the relationship between listening and writing skill improvement in his discussion on the impact of listening skill instruction on writing development.

In addition to the research on behalf of the positive effect of receptive skills practice over productive skills improvement, Fountas and Pinnell (2001) put the emphasis on "the interconnectedness of reading and writing" and claim it to be "profound and inescapable" (p. 6). According to them, using reading and writing together in a harmony can enable learners to improve in the complementary processes of reading and writing as they work to reflect themselves through the meaning they construct. Along with the positive effect of comprehension-based instruction in language acquisition, does specific writing skill instruction play any role on writing skill improvement on upper intermediate or advanced level students? When it comes to improving writing skill, according to A Guide to Effective Instruction in Writing (2005), specific instruction on writing can be said to be the basic instrument to teach students "to use to express their thoughts, feelings, and judgements about what they have read, seen, or experienced" (p. 12). As students continue to develop an understanding of the writing process, different text forms and genres, teachers should provide explicit instruction that will support students to express themselves more confidently and effectively. To teach students to communicate thoughts and experiences by writing clearly and creatively, writing teachers need to provide effective instruction in understanding the writing process, understanding the elements of writing, understanding audience, purpose, and form for writing and applying higher-order thinking skills (p. 13). Besides, Graham (2008) emphasizes that effective writing practices and specific writing teaching techniques have a proven record of success in enhancing students' writing on multiple occasions and he provides recommendations for teaching writing dedicating time to writing, with writing occurring across the curriculum, and involve students in various forms of "writing over time, increasing students' knowledge about writing, fostering students' interest, enjoyment, and motivation to write, helping students become strategic writers, teaching basic writing skills to mastery, taking advantage of technological writing tools, and finally using assessment to gauge students' progress and needs" (p. 2).

In addition, Graham and Perin (2007) present 11 elements of effective writing skill instruction as a result of their meta-analysis, performed to determine which elements 
of existing instructional methods, used in adolescent writing skill instruction are reported to be effective by research, and identify them as follows:

- Writing Strategies; teaching students strategies for planning, revising, and editing their compositions

- Summarization; explicitly and systematically teaching students how to summarize texts

- Collaborative Writing; using instructional arrangements in which adolescents work together to plan, draft, revise, and edit their compositions

- Specific Product Goals; assigning students specific, reachable goals for the writing they are to complete

- Word Processing; employing computers and word processors as instructional supports for assignments

- Sentence Combining; teaching students to construct more complex, sophisticated sentences

- Prewriting; engaging students in activities designed to help them generate or organize ideas

- Inquiry Activities; engaging students in analyzing immediate, concrete data to help them develop ideas and content for a particular writing task

- Process Writing Approach; interweaving a number of writing skill instructional activities in a workshop environment that stresses extended writing opportunities, writing for authentic audiences, personalized instruction, and cycles of writing

- Study of Models; providing students with opportunities to read, analyze, and emulate models of good writing

- Writing for Content Learning; using writing as a tool for learning content material (p. 11).

Among these 11 key elements, process writing skill instruction serves as the backbone for effective writing skill instruction. Process writing skill instruction should also be characterized by extensive opportunities for writing, writing for authentic audiences and purposes, engaging in cycles of planning, translating, and reviewing, personal responsibility and ownership of writing projects, self-reflection and evaluation, supportive writing environment; and individualized assistance and instruction (Troia, 2014).

In light of the research on behalf of the effect of comprehension-based instruction and of specific writing skill instruction over writing skill development, the present study aims to assess the role of Essay Writing Course, given along with a comprehension based program, on the writing performance of the foreign language learners at high school level. In other words, the present research basically focuses on this central question: Along with the positive effect of comprehension-based instruction in language acquisition, does specific writing skill instruction play any role on writing skill improvement of upper intermediate or advanced level high school students? Investigating the effect of Essay Writing course on the writing skill 
development of high school students, the present research also intends to prove the following hypothesis:

- Comprehension-based instruction has a positive effect on the writing skill improvement of high school students who do not take any writing skill instruction. (There is an increase in between the pre- and post-tests of control group; 12th graders of 2014-2015 academic year.)

- Essay Writing Course, given along with comprehension based instruction has a positive effect on the writing skill improvement of high school students. (There is an increase in between the pre- and post-tests of experimental group; 12 th graders of 2015-2016 academic year, before and after taking Essay Writing Course.)

- Essay Writing Course, given along with comprehension based instruction contributes more to the students' writing skill improvement than a mere comprehension-based instruction with no emphasis on writing skill instruction. (Experimental group is more successful than control group in terms of post-tests' and achievement levels' comparison.

\section{Method}

This study is a quantitative research conducted in true experimental design. The study was carried out on all sections of 12 th grade students and the former graduates of a state boarding high school. One experimental and one control group each containing 202 12th grade students formed the subjects of the study. The experimental group consists of 12th grade students in 2015-2016 educational year whereas the control group were the former graduates in the previous academic year of 2014-2015. The subjects in both experimental and control groups all came from standard state secondary schools where they took three hours of English education for three years in which the lessons were done as grammar rule teaching and memorization of the vocabulary. In parallel, members of both groups had similar educational background from the previous grades in this high school. The same number of hours of education per week (18 hours per week) was allotted for both groups. Besides, the educational facilities at the school were at the service of both groups. In addition, they also studied and lived in similar environment during and after the lessons. The ages of the group members were identical too; they are all 16-17 years old. The researcher herself was the instructor of both experimental and control groups. As a common procedure, all students were given a test of proficiency at the beginning of the year. All the classes in both groups can be said to be formed homogeneously.

Working as an instructor of English at this state high school, the researcher prefers to narrow down the population to this state high school as it is impossible to reach all high school students. The researcher and the facilitator of the study carries out the research on 12th grade students who undertake Essay Writing Course, specified on writing skill instruction and practice. Being an instructor of 12 th graders, the researcher can easily get in touch with and carry out the experimental research on her own students. The researcher's using convenience sampling technique in selecting 
the subjects of this experimental research to eliminate the difficulty of time may be considered as the only limitation of the study.

For the validity and reliability of the study, several tests are applied on the pre-test conducted on the experimental group. To test face and content validity of the writing exam employed as pre-test, three instructors of English who are also experienced in teaching writing are asked to fill out a short questionnaire in 5 point Likert scale form. The questionnaire consists five questions about the validity of the exam which are as follows: "The exam is comprehensive enough in measuring the objectives of the course.", "Each question in the exam reflects the writing objectives.", "The time given in the exam is adequate.", "There is adequate number of questions.", and "I feel the assessment is an adequate measure of writing ability". A basic statistical study based on correlation among three experts' views shows that there is a high correlation among three experts' views ( $p=0,78)$, therefore the exam can be said to be highly valid. To test intra-rater reliability, Essay Writing Exam, applied as pre-test is evaluated again by another instructor of English. The initial results from the evaluation of the Essay Writing course instructor who is also the facilitator of the study is compared with the results from the second evaluation of another instructor of English, and a high correlation is found in between $(p=0,71)$ which proves that the achievement test has intra-rater reliability. To test predictive validity as criterion-related validity, linear regression analysis is applied on pre-test and OPT-Oxford Placement Test which is a proficiency test in English. As the result of the relation analysis high regression is found $(\mathrm{r}=0,74)$ which means that the Essay Writing exam is a meaningful predicator of the general English proficiency test, OPT $(R=0,859$, $\left.\mathrm{R}^{2}=0,738, \mathrm{p}<0.01\right)$.

In the state high school, where the present study is conducted, Foreign Language Department principally and basically puts the emphasis on comprehension-oriented instruction, based on comprehensible input in the form of listening and reading practices in all four grades' English lessons. Mere rhetorical lessons on writing skill instruction, which are "Composition Writing" and "Essay Writing" are given in two terms, only in 12th grade. In the control group, a complete comprehension-based approach is applied in language teaching. In other words, the purpose of English course in control group is to present as much comprehensible input as possible in a completely stress and anxiety free environment. Therefore, the control group took 12 hours of listening practice, usually in the form of listening comprehension exercises or in natural conversations about daily matters. In addition to these listening activities in class, the teachers of the control group give the students 6 hours of free reading in class which is called as sustained silent reading sessions. Apart from all these, writing practice was totally absent in the language classes of control group. Thus, students had no formal writing practice or writing skill instruction. The pre-test was conducted on control group in the beginning of the 2nd term of 2014-2015 academic year whereas the post-test is conducted at the end of 2014-2015 academic year in which the students receives no writing skill instruction, apart from comprehension-based instruction. In the experimental group, the researcher assumes that language 
learning is a conscious process of rule learning through practice and applies an explicit and intensive instruction of writing in 8 hours per week. The instructor and the researcher goes over each Essay Type, explained in the textbook, "Writers at Work", gives sample essays to demonstrate and explains the process and principles of essay writing. The instructor applies process writing through writing cycles. In each essay type, the instructor presents the principles in the main stages as preparing outline, forming the thesis statement, determining the scope of the essay, organizing the essay in three parts as introduction, body and conclusion, forming the first draft, peer check, forming the final draft, and progress check. Throughout the lesson, the instructor also gives the students the chance of discovering the features of the objective essay type in group work, revising the newly learned essay writing principles through their friends' writing mistakes in peer work, and of assessing their own progress in between first and final draft of writing. During all writing process, the instructor also provides guidance for the students to write accurately. The writing skill instruction is carried out along with comprehensible skill practice with sustained silent reading sessions and listening practices in 4 hours each. In addition, she focuses on form and correct production of the structures in students' writings in a separate 2-hour grammar course every week. This treatment is carried out in 17 weeks all throughout the 2nd term of 2015-2016 academic year. The pre-test on experimental group is conducted before any writing skill instruction is given in the beginning of 2015-2016 academic year whereas the post-test is conducted after the experimental group students undertake Essay Writing Course at the end of the academic year. Table 1 summarizes the difference in treatment between the two groups.

Table 1. Average Amount of Activities during Classes

\begin{tabular}{llll}
\hline $\begin{array}{l}\text { Activities (18 class } \\
\text { hours/week) }\end{array}$ & Control Group & Experimental Group \\
\hline During Classes & Grammar & 0 & 2 \\
\cline { 2 - 4 } & Listening & 12 & 4 \\
\cline { 2 - 3 } & Writing & 0 & 8 \\
\hline & Sustained Silent Reading & 6 & 4 \\
\hline
\end{tabular}

The Statistical Package for Social Sciences (SPSS) was used for the analysis of the data obtained during the research. T statistics (t- test) were computed in accordance with the objectives of the study. Independent sample t-tests are used to test if two pre-tests are equal according to the mean scores or if there is a significant difference in between. In addition, paired sample t-tests are conducted in between the pre- and post-tests applied on experimental and control groups, to calculate the achievement 
levels of the groups. Finally, to compare the achievement levels, a final independent $t$ test is conducted in between the achievement of both groups. All the results are interpreted according to the level of significance $(p<0,05)$. The experimental design employed through the study is shown in Table 2.

Table 2. True Experimental Design

\begin{tabular}{llll}
\hline Study Groups & Pre-test & Treatment & Post-test \\
\hline $\begin{array}{l}\text { Experimental Group } \\
\text { 12th grades in 2015- }\end{array}$ & $\begin{array}{l}\text { 1st Essay Writing } \\
\text { Exam }\end{array}$ & Essay Writing Instruction & 3rd Essay \\
& & & Writing Exam \\
$\begin{array}{l}\text { Control Group } \\
\text { Graduates of 2014-2015 }\end{array}$ & 1st Writing Exam & $\begin{array}{l}\text { Comprehension-based Instruction } \\
\text { with no Writing Skill Instruction }\end{array}$ & 3rd Writing \\
\hline
\end{tabular}

\section{Results}

In the first phase of the research, an independent t-test is conducted to find out if the pre-tests applied on both groups in the beginning of each academic year are equal or if there is a significant difference in between. The results are shown in Table 3.

Table 3. Independent T-test Results related to the Comparison between 1st Writing Exam Scores (Pretests) of Experimental and Control Group

\begin{tabular}{|c|c|c|c|c|c|c|c|c|}
\hline Groups & $\mathrm{N}$ & $x$ & $\mathrm{sd}$ & $x_{1} x_{2}$ & $\mathrm{df}$ & $\mathrm{t}$ & $\mathrm{P}$ & Significance \\
\hline Control & 138 & 62.58 & 10.57 & \multirow{3}{*}{0.34} & \multirow{3}{*}{274} & \multirow{3}{*}{-0.23} & \multirow{3}{*}{0.81} & \multirow{3}{*}{ * } \\
\hline & & & & & & & & \\
\hline Experimental & 138 & 62.92 & 13.45 & & & & & \\
\hline
\end{tabular}

According to the results of independent t-test conducted in between the pre-tests of experimental and control groups, as it can be clearly seen in Table 3, the pre-test score of control group on writing achievement is $\bar{x}_{1}=62.58$ and that of experimental group is $\bar{x}_{2}=62.92$. The difference in between the writing scores of control and experimental group students $\bar{x}_{1}-\bar{x}_{2}=0.34$ is not found significant at a confidence level of $\propto=0.05$ [ $\mathrm{t}(274)=-0.23 ; \mathrm{p}<0.05]$. As there is no significant difference in between the writing scores of control and experimental groups, it apparently means that the pretests applied on control and experimental groups can be said to be equal. So, further research can be applied to test the indicated hypothesis.

The first hypothesis in the research is "Comprehension-based instruction has a positive effect on the writing skill improvement of high school students who do not take any writing skill instruction". In other words, "There is an increase in between the pre- and post-tests of control group (12th graders of 2014-2015 academic year)". To test this hypothesis, a paired sample t-test is conducted between pre- and post-test which are the 1st and 3rd Essay Writing exams of control group students, the 12th 
graders of 2014-2015 academic year, who do not undertake any writing skill instruction, apart from comprehension-based instruction. The results of the analysis of paired sample t-test on control group are shown in Table 4.

Table 4. Paired Sample T-test Results related to the Comparison between the 1st and 3rd Essay Writing Exam Scores (Pre- and Post-tests) of Control Group

\begin{tabular}{crrrrrrrr}
\hline Groups & $\mathrm{N}$ & $\bar{x}$ & $\mathrm{sd}$ & $\begin{array}{c}- \\
\bar{x}_{1}-\bar{x}_{2}\end{array}$ & $\mathrm{df}$ & $\mathrm{t}$ & $\mathrm{P}$ & Significance \\
\hline pre-test & 138 & 62.58 & 10.57 & & & & \\
post-test & 138 & 67.24 & 12.02 & & & & & \\
\hline $\mathrm{P}<0.05$ & & & & & & & & \\
\hline
\end{tabular}

According to the results of paired sample t-test conducted in between the pre-test and post-test of control group, the pre-test score of control group on writing achievement is $\bar{x}_{1}=62.58$ whereas post-test score is $\bar{x}_{2}=67.24$. The difference in between pre- and post-test scores $\bar{x}_{1}-\bar{x}_{2}=4,66$ is found significant at a confidence level of $\propto=0.05$ [t $(137)=-3.42 \mathrm{p}<0.05]$. This result, indicating an increase in the writing scores of control group students proves the first hypothesis. The significant increase in between the first and the last writing exam scores of the students who do not take Essay Writing Course can be said to indicate that regular comprehension-based instruction with no specific emphasis on writing skill instruction or writing skill practice has also a positive effect on the writing skill development of students.

The second hypothesis of the study is "Essay Writing Course, given along with comprehension based instruction has a positive effect on the writing skill improvement of high school students". In other words, "There is an increase in between the pre- and post-tests of experimental group (12th graders of 2015-2016 academic year, before and after taking Essay Writing Course)". To test this hypothesis, a second paired sample t-test is conducted in between pre- and post-test which are the 1st and 2nd Writing Exam applied on the experimental group students, the 12th graders of 2015-2016 academic year, who undertake the Essay Writing Course, along with comprehension-based instruction. The results are demonstrated in Table 5 as follows.

Table 5. Paired Sample T-test Results related to the Comparison between the 1st and 3rd Essay Writing Exam Scores (Pre- and Post-tests) of Experimental Group

\begin{tabular}{|c|c|c|c|c|c|c|c|c|}
\hline Groups & $\mathrm{N}$ & $x$ & sd & $\bar{x}_{1}-\bar{x}_{2}$ & $\mathrm{df}$ & $\mathrm{t}$ & $\mathrm{P}$ & Significance \\
\hline pre-test & 138 & 62.92 & 13.45 & \multirow{3}{*}{9.42} & \multirow{3}{*}{137} & \multirow{3}{*}{-5.56} & \multirow{3}{*}{$<0.0001$} & \multirow{3}{*}{$*$} \\
\hline & & & & & & & & \\
\hline post-test & 138 & 72.34 & 14.66 & & & & & \\
\hline
\end{tabular}

According to the results of paired sample t-test conducted in between the pre-test and post-test of control group, the pre-test score of control group on writing achievement is $\bar{x}_{1}=62.92$ whereas post-test score is $\bar{x}_{2}=72.34$. The difference in 
between pre- and post-test scores $\bar{x}_{1}-\bar{x}_{2}=9.42$ is found significant at a confidence level of $\propto=0.05$ [t $(137)=-5.56 ; \mathrm{p}<0.05$ ]. This result, showing an increase in the writing scores of experimental group students can prove the first hypothesis. It can be concluded that the treatment, the Essay Writing Course based on writing skill instruction which is carried out in between pre- and post-tests leads to a significantly positive effect on writing skill development and success of the students.

The third hypothesis is "Essay Writing Course, given along with comprehension based instruction contributes more to the students' writing skill improvement than a mere comprehension-based instruction with no emphasis on writing skill instruction". In brief, "Experimental group is more successful than control group in terms of posttests' and achievement levels' comparison". This hypothesis also means Essay Writing Course, along with comprehension-based instruction contributes more to the students' writing skill improvement than mere comprehension-based instruction with no writing skill instruction does. Therefore, it is the core hypothesis of the study which is basically focused on. In the research, this very important hypothesis is tried to be proven in two procedures; an independent t-test between the post-tests of experimental and control groups and another independent t-test in between the achievement levels of both groups. Table 6 shows the results of the independent t-test conducted in between the post-tests of experimental and control groups.

Table 6. Independent Sample T-test Results related to the Comparison between Final Writing Exam Scores (Post-tests) of Experimental and Control Groups

\begin{tabular}{|c|c|c|c|c|c|c|c|c|}
\hline Groups & $\mathrm{N}$ & $\underline{3}$ & sd & 齐1- & $\mathrm{df}$ & $\mathrm{t}$ & $\mathrm{P}$ & Significance \\
\hline pre-test & 138 & 67.24 & 12.02 & \multirow{3}{*}{5.0} & \multirow{3}{*}{274} & \multirow{3}{*}{-3.15} & \multirow{3}{*}{0.0017} & \multirow{3}{*}{$*$} \\
\hline & & & & & & & & \\
\hline post-test & 138 & 72.34 & 14.66 & & & & & \\
\hline
\end{tabular}

According to the results of independent t-test conducted in between the post-tests of experimental and control groups, the post-test score of control group on writing achievement is $\bar{x}_{1}=67.24$ and that of experimental group is $\bar{x}_{2}=72.34$. The difference in between the writing scores of control and experimental group students $\bar{x}_{1}-\bar{x}_{2}=5.10$ is found significant at a confidence level of $\propto=0.05$ [ $\mathrm{t}(274)=-3,15 ; \mathrm{p}<0.05]$. The results show that the post-test scores of experimental groups are significantly higher than the post-test scores of control group. Therefore, it can be said to prove that Essay Writing instruction which is the mere difference in treatment on both groups leads to a better improvement and an apparent success in writing skill.

As an independent-t test between the post-tests of the groups cannot be meaningful enough to indicate that experimental group is significantly more successful than control group, a second independent t-test in between the achievement levels of the groups is conducted along with the comparison of the post-test scores. This second ttest between the achievement levels of the groups also attempts to prove the core hypothesis of "Experimental group having Essay Writing instruction is more 
successful than the control group receiving a comprehension-based instruction, but no specific instruction on writing".

Table 7. Independent Sample T-test Results related to the Comparison between the Achievement Levels of Experimental and Control Groups

\begin{tabular}{|c|c|c|c|c|c|c|c|c|}
\hline Procedures & $\mathrm{N}$ & $x$ & $\mathrm{sd}$ & $\bar{x}_{1}-\bar{x}_{2}$ & $\mathrm{df}$ & $\mathrm{t}$ & $\mathrm{P}$ & Significance \\
\hline \multirow[t]{2}{*}{ Experimental } & 138 & 9.42 & 19.52 & & & & & \\
\hline & & & & 4.76 & 271 & -2.50 & 0.0012 & * \\
\hline Control & 138 & 4.66 & 10.74 & & & & & \\
\hline
\end{tabular}

According to the results of independent t-test conducted in between the achievement levels of experimental and control groups, the achievement of experimental group is $\bar{x}_{1}=9.42$. Achievement of control group is $\bar{x}_{2}=4.66$. The difference in between achievement levels of experimental and control group students $\bar{x}_{1}-\bar{x}_{2}=4.76$ is found significant at a confidence level of $\propto=0.05$ [t $\left.(271)=-2.50 ; p<0.05\right]$. The results show that the achievement of experimental group is significantly higher than the achievement of control group. This final comparison between the achievement levels of the groups apparently indicates that the experimental group is more successful than the control group in terms of the students' achievement level in writing exam scores. Thus, it can be said to prove for the second time that Essay Writing instruction along with comprehension-based instruction leads to a better improvement and success in writing skill rather than mere comprehension-based instruction with no special emphasis and instruction on writing skill.

\section{Discussion}

Writing skill is one of the key components of language learning not only in educational but also in social life for lifelong learners (Inal, 2006). However, many researchers indicate the unfortunate fact that teaching and learning writing skill is rather a struggling period in the world and our country (Deniz, 2000). The challenging nature of learning and improving writing skill has led to numerous educational researchers on how to teach writing and maintain writing skill improvement. Two distant viewpoints on the issue of writing skill development are presented within the scope of this research. The control and experimental groups, as the representatives of these views are compared and analyzed in true experimental design in the present study.

The first view claims that a comprehension, and receptive skill (reading and listening) based instruction is the way to success in language acquisition and proficiency (Bozorgian 2012; Gradman \& Hanania, 1991; Hitosugi \& Day 2004; Krashen 1994, 2003; Smith, 2003), including writing skill improvement (Berninger 2000; Paribakht \& Wesche, 1993; Shanahan 2006). In the study, this first view is represented by the control group students, who were the graduates of the state high school, where the study takes place, in the previous academic year of 2014-2015, and 
who did not receive any rhetorical instruction on writing, apart from comprehensionbased instruction with listening and reading practice. In accordance with the view of Mason (2006), Beglar, Hunt and Kite (2011), and Trelease (2013) on behalf of the positive effect of free pleasure reading on overall language proficiency and skill improvement, control group is subjected to excessive amount of reading for pleasure, in 2-hour silent reading sessions. Control group did not receive any instruction on grammar or writing skill, apart from comprehension-based instruction, emphasizing excessive comprehensible input in the form of listening and reading skill practice, completely free from any deliberate teacher or peer correction (Truscott, 2004, 2005). In the scope of the present study, the paired sample t-test, applied on pre- and posttests of control group indicates a significant increase, therefore contributes to the studies on behalf of the positive effect of comprehension-based instruction over writing skill improvement.

The second view puts the emphasis on writing skill instruction and teaching writing rules for writing skill improvement, (Graham, 2008; Graham \& Perin, 2007). In the study, this view is represented by the experimental group students, who are the 12th graders of 2015-2016 academic year and who take the 8-hour Essay Writing Course along with the school's comprehension-based policy in foreign language teaching. In parallel to the studies of Pantier (1999), Saddler and Graham (2005), a supplementary Grammar Course, which is based on sentence combining, to teach students construct more complex and sophisticated sentences in upper levels, instead of traditional grammar, is given in a separate 2-hour lesson, along with the Essay Writing Course. The experimental group undertakes Essay Writing Course as specific writing skill instruction, along with comprehension-based instruction and reading skill practices in parallel with the view of Fountas and Pinnell (2001) who believe in the "interconnectedness" of reading and writing skills in language development. In the beginning of each Essay Writing lesson, the instructor, the researcher as well, teaches her students the objective essay type writing strategies for planning, revising, and editing their writings, in accordance with the studies of Walser (2000), Troia and Graham (2002), De La Paz (2005), and Graser (2005). All through out every Essay Writing lesson, she also employs process writing approach, supported by the work of Reimer (2001) and Troia (2014), according to which she renders writing activities in a way to create a workshop and supportive writing environment in which the students get the chance of having personal responsibility of their own writing projects, making self-reflection and evaluation, and receiving individualized assistance and instruction. Within process writing approach, she also guides her learners write independently and form their first draft of writing on their own with direct grammatical or organizational correction when needed as it is suggested by Fearn and Farnan (2005). Beside this individual type of instruction, with which each student can have the chance of writing, and then evaluating his progress on his own, the instructor also gives her students the opportunity to work in peers or groups, to revise, to edit, and to learn from each other's writing mistakes under a collaborative writing instruction, recommended by Yarrow and Topping (2001), and Boscolo and Ascorti (2004). 


\section{Conclusions}

In the scope of the present study, a series of independent t-tests and paired sample t-tests are conducted to make a comparison in between the writing scores and achievement levels of the experimental and control groups before and after the treatment of Essay Writing Course, along with comprehension-based instruction. As a result of all the independent and paired sample t-tests carried out through the study, it can be concluded that the experimental group, given the Essay Writing Course is significantly more successful than the control group, not given any specific writing skill instruction, apart from comprehension-based instruction. Within the analysis of paired sample and independent t-tests, as the central focus and the basic conclusion of the study, it can be claimed that Essay Writing Course has a positive effect over the writing skill development of high school students. In addition to a regular instruction, based on writing strategies and process writing in Essay Writing Course, the researcher's constant effort to create a writing workshop and a friendly and supportive writing environment that provides students with the opportunity of working individually, and collaboratively in peers and in groups in which they can brainstorm, plan, organize, write, assess, evaluate, and observe their overall progress, can be said to be the key factor that leads to success in experimental group students' writing performance.

According to the results, derived from the analysis of the tests, the most important points that can also be concluded are listed as follows:

- The high school students who are high-intermediate or advanced level learners of English can benefit from Essay Writing Course for their writing skill improvement.

- The high school students who are high-intermediate or advanced level learners of English can benefit from a constant comprehension-oriented instruction, based on and reading-listening skill practices instruction for their writing skill improvement.

- The high school students who are high-intermediate or advanced level learners of English can apparently progress more in writing when subjected to Essay Writing Course along with comprehension-oriented instruction.

- Comprehension-oriented instruction, based on reading and listening skills practice can have a positive effect over writing skill development throughout four-year high school education period. However, additionally, a writing course, based on understanding and learning different writing purposes, rules, principles, processes, styles and genres, is crucially needed to polish and improve writing skill in highintermediate and advanced levels.

\section{Recommendations}

After all the conclusions, derived from the analysis of the tests, conducted in the study, the following recommendations about writing skill instruction can be given as follows: 
- In beginner, elementary and intermediate levels of English, comprehension-based instructional approach can be beneficial in providing the learners with as much as possible amount of constant and comprehensible reading and listening input. In overall language acquisition, writing skill improvement can be partially achieved by the positive transfer from reading and listening skill practices. However, in highintermediate and advanced levels, comprehension-based instruction should be enriched and reinforced with writing skill instruction to achieve a real progress in writing skill.

- As writing skill has a key role in educational, professional and social life, a rhetorical course on writing should be designed and placed in the curriculum of high schools, specifically in 12th grade, just before university education.

- While designing and implementing the writing course, the course designer and the instructor should always follow the cycles of planning, translating, and reviewing, individual, pair and group work in writing projects and assignments, and self and peer reflection and evaluation.

- Within this cycle of writing lesson, the instructor should aim to involve his students in various forms of and extensive opportunities for writing during the time, he dedicates to writing skill instruction.

- The instructor, while increasing students' knowledge about writing, should not neglect to foster his students' interest, enjoyment, and motivation to write.

- The instructor should teach basic writing skills to mastery.

- The instructor should never hesitate to spare his time to focus on form and to correct production of grammatical structures, when needed.

- In addition to the course book, the instructor should also take advantage of technological writing tools, which today's young learners are more interested in.

- At the end of each piece of instruction, focusing on a specific topic, writing type or genre, the instructor should use constant and regular assessment, evaluation and feedback to gauge students' progress and needs in writing skill.

- In addition to explicit and intensive instruction of writing, sustained silent reading sessions and listening practices should be given place in English lessons, as well.

\section{References}

A Guide to Effective Instruction in Writing, Ontario Education, Queen's Printer for Ontario, 2005, 12-13.

Beglar, D., Hunt, A., \& Kite, Y. (2011). The effect of pleasure reading on Japanese university EFL learners' reading rates. Language Learning, 62(2), 1-39.

Berninger, V. (2000). Development of language by hand and its connections to language by ear, mouth and eye. Topics in Language Disorders, 20,65-84.

Boscolo, P., \& Ascorti, K. (2004). Effects of collaborative revision on children's ability to write understandable narrative texts. In L. Allal, L. Chanquoy, \& P. Largy (Eds.), Revision: Cognitive and instructional processes (157-170). Boston: Kluwer Academic Publishers. 
Bozorgian, H. (2012). The Relationship between listening and other language skills in International English Language Testing System (IELTS). Theory and Practice in Language Studies, 2 (4), 657-663.

De La Paz, S. (2005). Teaching historical reasoning and argumentative writing in culturally and academically diverse middle school classrooms. Journal of Educational Psychology, 97, $139-158$.

Deniz, K. (2000). Yazllı anlatım becerileri yönünden köy ve kent beșinci sinıf öğrencilerinin durumu (Basılmamıs Yüksek Lisans Tezi). Çanakkale Onsekizmart Üniversitesi Sosyal Bilimler Enstitüsü, Çanakkale.

Fearn, L., \& Farnan, N. (2005). An investigation of the influence of teaching grammar in writing to accomplish an influence on writing. Paper presented at the annual meeting of the American Educational Research Association, Montreal, Canada.

Fountas, I.C., \& Pinnell, G.S. (2001). Guiding readers and writers, Grades 3-6. Portsmouth, $\mathrm{NH}$ : Heinemann.

Glaser, C. (2005). Improving the fourth-grade students' composition skills: Effects of strategy instruction and self-regulatory procedures (Unpublished doctoral dissertation). University of Pottsburg, Germany.

Gradman, H. L., \& Hanania, E., (1991). Language learning background factors and ESL proficiency. The Modern Language Journal, 75(1) 39-51.

Graham S, (2008). Effective writing instruction for all students, for renaissance learning. Vanderbilt University, Wisconsin Rapids USA.

Graham, S., \& Hebert, M. (2011). Writing-to-read: A meta-analysis of the impact of writing and writing instruction on reading. Harvard Educational Review, 81, 710-744.

Gökalp, G., \& Gonca, A., (2001). Derslikten günlük yaşama edebiyat eğitimi. Türkbilig 2000/ITürkoloji Arasstırmaları, 185-202.

İnal, S. (2006). Ingilizce yazılı anlatım dersinin sorunları üzerine bir inceleme. Journal of Language and Linguistic Studies, 2(2).

Hitosugi, C. I., \& Day, R. (2004). Extensive reading in Japanese. Reading in a Foreign Language, 16(1).

Krashen, S. (1994). The input hypothesis and its rivals. In N. Ellis (Ed.), Implicit and explicit learning of languages (45-77). London, England: Academic Press.

Krashen, S. (2003). Explorations in language acquisition and use: The Taipei lectures. Portsmouth, NH: Heinemann.

Mason, B. (2006). Free voluntary reading and autonomy in second language acquisition: Improving TOEFL scores from reading alone. International Journal of Foreign Language Teaching, 2(1), 2-5.

Pantier, T. F. (1999). A comparison of writing performance of fifth grade students using the process writing approach and the Shurley Method (Unpublished doctoral dissertation). Oklahoma State University, Stillwater.

Paribakht, T. S., \& Wesche, M.B., (1993). Reading comprehension and second language development in a comprehension-based ESL program. TESL Canada Journal, 11(1),9-12.

Reeves, D, (2000). Accountability in action. Denver, CO: Advanced Learning Press.

National Center for Education Statistics. (1997). Reading and Writing Habits of Students, The Condition of Education.

Reimer, M. (2001). The effect of a traditional, a process writing and a combined talking and writing instructional approach on the quality of secondary English students' written response (Unpublished master's thesis). University of Manitoba, Canada. 
Saddler, B., \& Graham, S. (2005). The effects of peer-assisted sentence-combining instruction on the writing performance of more and less skilled young writers. Journal of Educational Psychology, 97, 43-54.

Shanahan, T. (2006). Relations among oral language, reading and writing development. In A. C. MacArthur, S. Graham, \& J. Fitzgerald, Handbook of writing research. The Guidford Press.

Smith, F. (2003). Understanding reading: A psycho- linguistic analysis of reading and learning to read. Mahwah, NJ: Erlbaum.

Smart, G. (2008). Writing and the social formation of economy. In. C. Bazerman (Ed.), Handbook of research on writing: History, society, school, individual, text (p. 103-112). NA.

Snow, C. E., \& Biancarosa, G. (2003). Adolescent literacy and the achievement gap: What do we know and where do we go from here? New York: Carnegie Corporation of New York.

Trelease, J. (2013), Sustained Silent Reading, The New Read-Aloud Handbook. New York: Penguin Books Publishing.

Troia, G, (2014) Evidence-based practices for writing instruction, Michigan State University, September 2014, CEEDAR Document No. IC-5.

Truscott, J. (2004). Evidence and conjecture on the effects of error correction: A response to Chandler. Journal of Second Language Writing, 13, 337-343.

Truscott, J. (2005). The continuing problems of oral grammar correction. International Journal of Foreign Language Teaching, 1(2), 17-22.

Troia, G., \& Graham, S. (2002). The effectiveness of a highly explicit, teacher-directed strategy instruction routine: Changing the writing performance of students with learning disabilities. Journal of Learning Disabilities, 35, 290-305.

Walser, T. M. (2000). Teaching self-management of writing strategies to promote transfer (Unpublished doctoral dissertation). Utah State University, Logan, UT.

Yarrow, F., \& Topping, K. J. (2001). Collaborative writing: The effects of metacognitive prompting and structured peer interaction. British Journal of Educational Psychology, 71, $261-282$.

\section{Copyrights}

Copyright for this article is retained by the author(s), with first publication rights granted to the Journal.

This is an open-access article distributed under the terms and conditions of the Creative Commons Attribution license (CC BY-NC-ND) (http://creativecommons.org/licenses/by-nc-nd/4.0/). 